\title{
Phenology of cocoa tree in a tropical moist forest
}

\author{
Fenologia do cacau em floresta tropical úmida
}

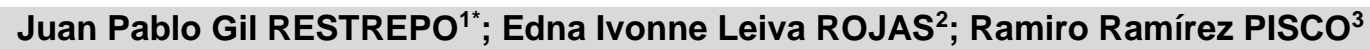

${ }^{1}$ Engenheiro agrônomo, Mestre em Ciências Agrárias. Universidad Nacional de Colombia, jpgilr@unal.edu.co.

2 Autor para correspondência, Engenheira agrônoma, MSc, Ph.D, Universidad Nacional de Colombia, Facultad de Ciencias Agrarias, Cl. 59 a \# 63 - 20 Medellín (Antioquia), eileiva@unal.edu.co

${ }^{3}$ Engenheiro agrônomo, MSc, Ph. D, Universidad Nacional de Colombia, rramirez@unal.edu.co

Recebido em: 24-01-2017; Aceito em: 20-03-2017

\begin{abstract}
Cocoa crop in Colombia is characterized by low technified systems, with yields below $500 \mathrm{~kg} \mathrm{ha}^{-1}$ year $^{-1}$. Inappropriate application of cultural practices related to the lack of knowledge about cocoa phenology, as to the times and factors that induce flowering, shoot growth and fruit filling, is one of the principal causes. Phenology of cocoa clones CCN-51, ICS-95, FCH-25 y LK-40 was characterized in 4 years old trees, data were taken monthly for one year in a Tropical moist forest (T-mf), with unimodal rainfall regime, in the municipality of Chigorodó (Antioquia), coordinates $7^{\circ} 36^{\prime} 52.5473^{\prime \prime} \mathrm{N}, 76^{\circ} 39^{\prime} 32.8495^{\prime \prime} \mathrm{W}$ and $30 \mathrm{~m}$ above sea level, Mi Fortuna farm. The correlation (Spearman) between precipitation, water balance, number of hours with photosynthetically active radiation between 750 and $2200 \mu \mathrm{mol} \mathrm{m}^{-2} \mathrm{~s}^{-1}$ (PAR hours) and the maximum and minimum temperature with vegetative and reproductive variables was calculated. A significant correlation $(p<0.001)$ between flowering and precipitation, water balance and PAR hours was found. Vegetative growth rate was controlled by fruit filling and harvest (source-sink ratio). The reproductive performance of LK-40 was superior to that of CCN-51 and similar to that of ICS-95 and FCH-25; clon CCN-51 showed the highest vegetative growth, but its reproductive performance was less than ICS-95 and LK-40.
\end{abstract}

Additional keywords: cocoa; flowering; shoot growth; source - sink ratio; Theobroma cacao.

\section{Resumo}

O cultivo de cacau na Colômbia apresenta produtividade média de grãos secos inferior a $500 \mathrm{~kg} \mathrm{ha}^{-1} \mathrm{ano}^{-1}$. Uma das causas é a aplicação inoportuna de práticas culturais, por desconhecimento da fenologia do cacau quanto às épocas e fatores que induzem a floração, a brotação de ramas e o enchimento dos frutos. Neste estudo, se objetivou caracterizar a fenologia dos clones de cacau CCN-51, ICS-95, FCH-25 e LK-40, em plantas de 4 anos. Os dados foram obtidos a cada 30 dias, durante um ano, em zona de floresta úmida tropical, localizada em Chigorodó (Antioquia, Colômbia), coordenadas 7 36' 52.5473" N e 76 39'32.8495" W, 30 m acima do nível do mar, fazenda Mi Fortuna. Se calculou a correlação (Spearman) entre a precipitação, o balanço hídrico, a quantidade de horas de radiação fotossinteticamente ativa entre 750 e $2200 \mu \mathrm{mol} \mathrm{m}^{-2} \mathrm{~s}^{-1}$ e a temperatura máxima e mínima com variáveis vegetativas e reprodutivas. Se evidenciou correlação significativa $(p<0,001)$ da floração com a precipitação, o balanço hídrico e a radiação. O ritmo de crescimento vegetativo foi determinado por crescimento e colheita dos frutos (relação fonte - dreno). O clone LK-40 apresentou comportamento reprodutivo superior ao de CCN-51 e semelhante ao de ICS-95 e FCH-25; o clone CCN-51 teve o maior crescimento vegetativo, mas seu desempenho reprodutivo foi menor que o dos clones ICS-95 e LK-40.

Palavras-chave adicionais: crescimento de ramas; floração; relação fonte - dreno; Theobroma cacao.

\section{Introduction}

The cocoa plant (Theobroma cacao L.) is a tree native to lowland rainforests of the Amazon River basins (Motamayor et al., 2002, Thomas et al., 2012) growing between $20^{\circ}$ latitude North and South of the Equator. Its seeds are the main raw material used to make chocolate (Fedecacao, 2015). Around 40-50 million people globally depend on cocoa for their livelihoods. In Colombia, cocoa is a traditional crop carried out by smallholders in hot climates with altitude between 0 and $1200 \mathrm{~m}$ it is an important source of employment. (Espinal et al., 2005). The national pro- duction is completely absorbed by the food industry (Castellanos et al., 2007). The production system has an average yield of less than $500 \mathrm{~kg} \mathrm{ha}^{-1}$ year ${ }^{-1}$. However, there are some technified plantations that can produce more than $2000 \mathrm{~kg} \mathrm{ha}^{-1}$ year-1 (Fedecacao, 2015). Reasons for the low productivity include the use of hybrids (instead of high-yielding clones), low planting densities $\left(<800\right.$ trees ha- $\left.{ }^{-1}\right)$, the lack of appropriate farm management techniques such as pruning, fertilization, and control diseases, due to ignorance of the floral phenology of cocoa trees, throw off branches and pod filling.

Plant phenology is poorly known for lowland 
tropical rain forest species (Borchert, 1983), although this ecosystem has the greatest diversity of phenological patterns. These studies has been most developed in the temperate zone where patterns are based on date or season, and the frequency of cycles are often annual. In tropical zone annual, subannual, continual or supra-annual phenological behavior can be presented (Newstrom et al, 1994). The vegetative and reproductive development are interrelated in all the plants, but in the trees the relations are considerably more complex for the structural heterogeneity, the periodic flowering and the alternation of periods of growth and dormant. Because of the importance and complexity of phenology, many studies have been conducted mostly in tropical environments especially for cocoa.

Few methodological studies have focused on tree phenology in tropical forests as the framework for the classification of plant phenology proposed by Newstrom et al. (1994) based on flowering patterns of trees in tropical moist forests. This methodology distinguished four classes based on frequency, defined as the number of "on"/"of" cycles per year: continual, subannual, annual and supra-annual. Sakai (2001) proposed an additional class for the non-flowering trees. Newstrom et al. (1994) suggested several indices, including regularity, duration, frequency, synchrony, and amplitude defined as the quantity or intensity of response.

For the specific case of cocoa, various authors have established that cocoa exhibits a season-related phenological pattern of flowering (Alvim, 1977, Omolaja et al., 2009), shoot-growth rhythms (Greathouse et al., 1971), physiological production model (Zuidema et al., 2005), flower development (Swanson et al., 2008), and seed filling duration (Hoopen et al., 2012), among others. Niemenak et al. (2010) adapted the $\mathrm{BBCH}$ scale to describe the phenological growth stages of cocoa tree from germination up to tree senescence, independent of variation in timing.

Phenological studies are being used as a tool for planning of management practices (Righi et al., 2001), for controlling plant diseases (Hoopen et al., 2012; Muller et al., 2004), in the study of ecological interactions between species (Boyle y Bronstein, 2012; Borchert, 1983) and the development of applied research methodologies (Niemenak et al., 2010). This research aims to characterize cocoa phenology in tropical moist forest conditions (bh-T), considering the great potential for production of this life zone both in Colombia and in the rest of the world.

\section{Material and methods}

\section{Location}

This study was conducted in the municipality of Chigorodó (Antioquia), coordinates 7 36'52.5473" N, 76 39'32.8495" $\mathrm{W}$ and $30 \mathrm{~m}$ above sea level, "Mi Fortuna" farm, located in the tropical moist forest (bh-T), according to the life zone classification system Holdridge adapted by Espinal (1977) to colombian conditions, with a unimodal precipitation regime.

\section{Plant material}

The evaluated clones were: CCN-51 (Universal), ICS-95 (Universal), LK-40 (Granja Luker 40), FCH-25 (Fedecacao Chigorodó 25), with ear index of 15.6, 20.7, 15.4 and 15.6 ears $\mathrm{kg}^{-1}$ and grain index of $1.5,1.3,1.4$ and $1.5 \mathrm{~g} \mathrm{grain}^{-1}$, respectively. The 4-yearold trees are planted at $3 \times 3 \mathrm{~m}$ distance for a total of 1111 trees ha $^{-1}$, in a shaded (Gliricidia sepium) distanced at $16 \mathrm{~m}$.

\section{Variables and Sampling}

During one year, between July 2014 and July 2015, every half hour was recorded with a weather station; Decagon Devices Inc. for measuring precipitation, temperature, relative humidity, wind speed, photosynthetically active radiation (PAR) and global radiation. Data were used to calculate reference evapotranspiration with the DataTrac $3 \circledast$ program that uses a modified FAO Penman-Montieth equation (Decagon Devices Inc., 2015), the water balance and the number of hours were measured by means of photosynthetically active radiation.

Every 30 days, measurements were made on 15 trees per clone, for counts of reproductive variables as number of open flowers, number of dry fruits, fruits from 0 to 2 months, from 2 to 4 months and more than 4 months. The dried fruits were removed from the trees in every sampling.

A branch was marked $30 \mathrm{~cm}$ from the apex in 10 trees of each clone. Every 30 days for one year, they were measured in length, number of buds on the main axis, number of branches developed and number of mature, and immature leaves to characterize the vegetative growth. The growth stages of the branches was described according to Greathouse et al. (1971):

- F1: apical bud swelling. Visible leaflets

- F2: leaves and internodes expansion.

- 11: apical bud dormant, covered by stipules. The new leaves have not completed their ripening process and have a reddish or pale green color.

- 12: Apical bud dormant. New leaves are ripe (green color). Stem without obvious lignification (green color). - 13: Apical bud dormant. Lignified stem (brown color).

\section{Statistical analysis}

\section{Relationship between climatic conditions and vegetative and reproductive cycles of cocoa}

A description of the meteorological variables was made with monthly data scatter plots. Precipitation, evapotranspiration, water balance and radiation hours of 750 to $2200 \mu \mathrm{mol} \mathrm{m} \mathrm{m}^{-2} \mathrm{~s}^{-1}$ were summarized as the period sum, and the average maximum and minimum temperature for the period. Estimates of reference evapotranspiration were made using the procedures given by Allen et al. (1998). The correlation (Spearman) (95\% confidence interval) between mete- 
orological factors and vegetative and reproductive growth variables was measured with the $R$ Project "Hmisc" package (R Core Team, 2015).

\section{Characterization of the phenology of regional and universal clones}

A comparison of the evaluated variables between clones and evaluation dates was performed by means of Kruskal-Wallis rank test (non-parametric test, 95\% confidence level) and post hoc tests for multiple comparisons by the Conover method (Conover 1999; Pohlert, 2014) with the "pgirmess", "agricolae" and "PMCMR" packages of R Project (R Core Team, 2015). The duration of the phenological stages was established from the maximum event occurrence. Phenological stages were described according to the $\mathrm{BBCH}$ scale for cocoa. This scale considers 10 principal growth stages numbered from 0 to 9 which describes plant development from germination up to tree senescence, independent of variation in timing, and in each one considers 10 secondary growth stages numbered from 0 to 9 , this combination gives a two-digit numeric code (Niemenak et al., 2010). The vegetative and reproductive patterns were also determined (Newstrom et al., 1994; Boyle and Bronsten, 2012).

For vegetative and reproductive variables, a Spearman's rank correlation analysis $(95 \%$ confidence interval) was performed with the R Project "Hmisc" package (R Core Team, 2015).

\section{Results and discussion}

Relationship between climatic factors and vegetative and reproductive cycles of cocoa

In the study area a unimodal rainfall regime was presented with a period of positive water balance between April and December and a negative water balance between January and March. Water availability was highest during the months of July (2015), November and September with values of 343, 291 and $270 \mathrm{~mm}$ month $^{-1}$, respectively. During the dry season the accumulated water deficit was $148.8 \mathrm{~mm}$, being February the driest month with a deficit of $92 \mathrm{~mm}$ month $^{-1}$ (Table 1).

August and September presented the lowest temperature and the highest was presented between March and April (Table 1, Figure1). The lowest relative humidity occurred in March $(64.1 \%)$, while the maximum values of this variable remained close to $100 \%$ throughout the year (Figure 2).

The negative water balance between January/2015 and March/2015 in the study area (Table 1) favored floral induction of cocoa, the water supply from April stimulated flower development up to anthesis, evidenced in a peak flowering at the end of June, possibly a period equal to or greater than that observed by Swanson et al. (2008) that have a duration of 30 days from the flower primordium formation up to anthesis.

The maximum flowering rate of the CCN-51, ICS-95, LK-40 and FCH-25 clones coincided with a period of positive water balance (June), preceded by three months of drought (January to March) in which the number of flowers was the lowest within the study period (Table 2; Figure 3). There was a significant correlation between the number of open flowers and rainfall $(p<0.001)$, also, between the total flowers and the water balance $(p<0.001)$, with values of 0.34 and 0.39 , respectively.

In this respect, Borchert (1983) has found that precipitation after dry periods was found to trigger anthesis in a similar way to that recorded in cocoa in this study area. In the same way, flowers formation in cocoa is stimulated by the transition from dry to rainy seasons as mentioned by Alvim (1977) and Omolaja et al. (2009). Moser et al. (2010) reported that, to a 13month desiccation period a reduction was observed in flowering and fruit set. Müller et al. (2004) managed to increase the number of flowers and prolong flowering periods of cocoa with hormonal manipulation and tree ringing during periods of water deficit.

Table 1 - Monthly data on rainfall, days without rainfall (DWR), reference evapotranspiration (ETo), water balance, hours with photosynthetically active radiation in the range of 750 to $2200 \mu \mathrm{mol} \mathrm{m}^{-2} \mathrm{~s}^{-1}$ (Hours PAR), maximum and minimum air temperature (Tmin and Tmax). July 2014 to July 2015.

\begin{tabular}{lccccccc}
\hline Date & Rainfall $(\mathrm{mm})$ & DWR & $\begin{array}{c}\text { ETo } \\
(\mathrm{mm})\end{array}$ & $\begin{array}{c}\text { Water } \\
\text { balance } \\
(\mathrm{mm})\end{array}$ & Hours PAR & $\begin{array}{c}\text { Tmin } \\
\left({ }^{\circ} \mathrm{C}\right)\end{array}$ & $\begin{array}{c}\text { Tmax } \\
\left({ }^{\circ} \mathrm{C}\right)\end{array}$ \\
\hline Jul-14 & 284.6 & 6 & 95.2 & 189.4 & 163.5 & 23.7 & 31.6 \\
Aug-14 & 279.0 & 8 & 93.9 & 185.1 & 162.5 & 23.0 & 31.2 \\
Sept-14 & 363.6 & 7 & 93.4 & 270.2 & 162.5 & 23.0 & 31.4 \\
Oct-14 & 309.4 & 11 & 91.0 & 218.4 & 153.5 & 23.2 & 31.1 \\
Nov-14 & 384.4 & 8 & 93.1 & 291.3 & 166.5 & 23.2 & 31.4 \\
Dec-14 & 150.0 & 16 & 88.7 & 61.3 & 145.0 & 23.4 & 31.0 \\
Jan-15 & 100.0 & 27 & 112.7 & -12.7 & 166.0 & 23.5 & 30.7 \\
Feb-15 & 12.8 & 19 & 105.2 & -92.4 & 159.0 & 24.5 & 31.6 \\
Mar-15 & 81.8 & 24 & 125.5 & -43.7 & 185.0 & 24.4 & 32.1 \\
Apr-15 & 155.2 & 16 & 92.8 & 62.4 & 145.5 & 24.4 & 32.0 \\
May-15 & 170.2 & 13 & 84.1 & 86.1 & 132.0 & 24.2 & 31.1 \\
Jun-15 & 330.0 & 5 & 79.3 & 250.7 & 133.5 & 24.1 & 31.7 \\
Jul-15 & 415.8 & 10 & 72.5 & 343.3 & 119.5 & 23.9 & 31.2 \\
\hline Total & 3036.8 & 170 & 1227.3 & 1809.5 & 1994 & 23.7 & 31.4 \\
\hline
\end{tabular}




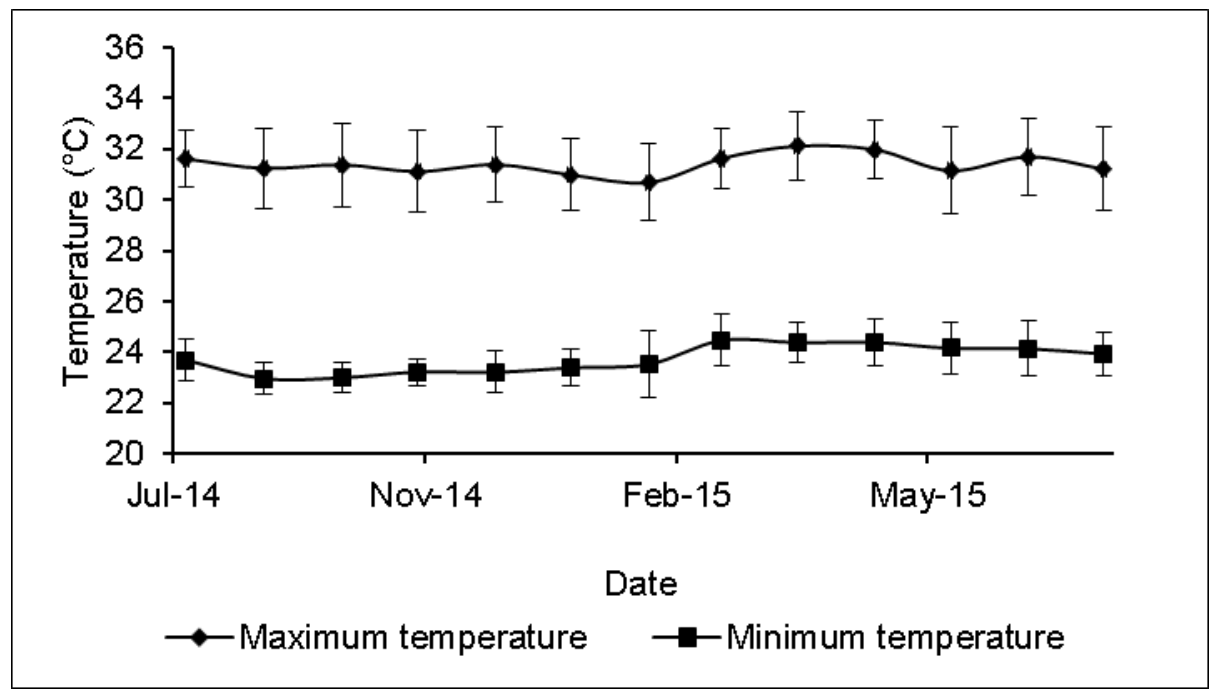

Figure 1 - Distribution of maximum and minimum daily temperatures $\left({ }^{\circ} \mathrm{C}\right)$ per month, between July 2014 and July 2015. bh-T.

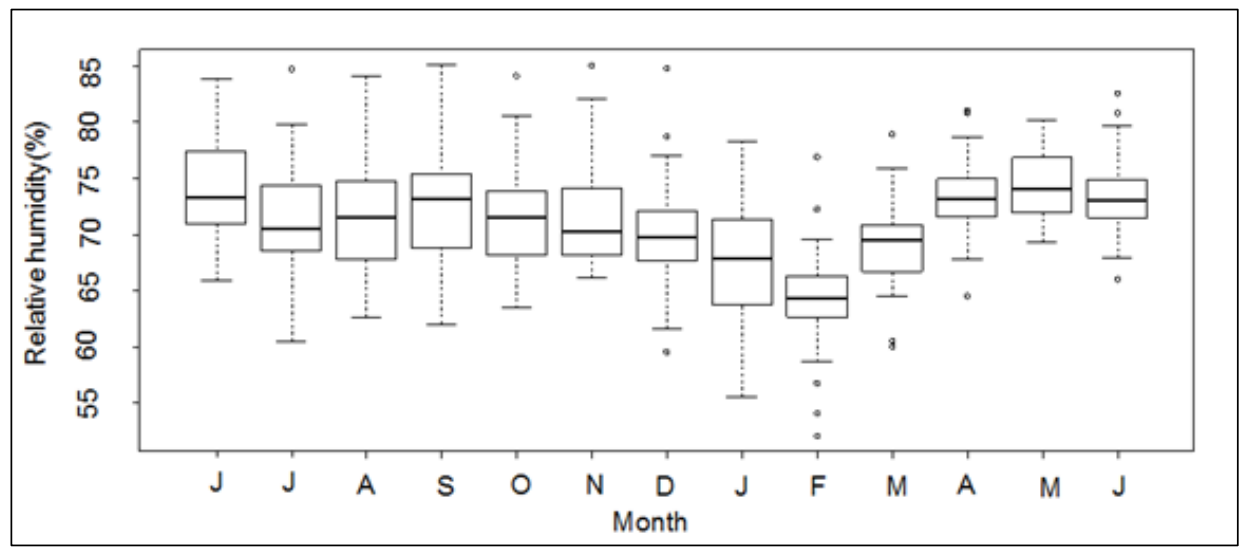

Figure 2 - Distribution of daily minimum air relative humidity, per month, between July 2014 and July 2015. bh-T.

Table 2 - Median $(\mathrm{M})$ of the reproductive variables by periods of evaluation for the clones $\mathrm{CCN}-51, \mathrm{FCH}-25$, ICS-95 and LK-40 in bh-T.

\begin{tabular}{|c|c|c|c|c|c|c|c|c|c|c|c|}
\hline \multirow{3}{*}{ Clone } & \multirow{3}{*}{ Period } & \multirow{2}{*}{\multicolumn{2}{|c|}{ \# Flowers tree ${ }^{-1}$ day $^{-1}$}} & \multicolumn{8}{|c|}{ Number of trees tree $^{-1}$ sampling $^{-1}$} \\
\hline & & & & \multirow{2}{*}{\multicolumn{2}{|c|}{$\frac{<2 \text { months }}{\mathrm{M}}$}} & \multirow{2}{*}{\multicolumn{2}{|c|}{$\frac{2 \text { to } 4 \text { months }}{M}$}} & \multirow{2}{*}{\multicolumn{2}{|c|}{$\frac{>4 \text { months }}{M}$}} & \multirow{2}{*}{\multicolumn{2}{|c|}{$\begin{array}{r}\text { Dry } \\
M\end{array}$}} \\
\hline & & \multicolumn{2}{|c|}{$\mathrm{M}$} & & & & & & & & \\
\hline \multirow{4}{*}{ CCN-51 } & Jul - Oct & 27 & $a^{1}$ & 24 & $\mathrm{a}$ & 8 & $\mathrm{a}$ & 4 & $\mathrm{a}$ & 10 & $\mathrm{a}$ \\
\hline & Nov - Jan & 2 & C & 2 & C & 3 & a & 2 & a & 7 & $\mathrm{~b}$ \\
\hline & Feb - Apr & 6 & $\mathrm{~b}$ & 0 & d & 0 & $\mathrm{~b}$ & 0 & $\mathrm{~b}$ & 0 & $\mathrm{c}$ \\
\hline & May - Jul & 46 & $\mathrm{a}$ & 4 & $\mathrm{~b}$ & 0 & $\mathrm{C}$ & 0 & C & 0 & C \\
\hline \multirow{4}{*}{$\mathrm{FCH}-25$} & Jul - Oct & 13 & a & 8 & $\mathrm{a}$ & 0 & $\mathrm{C}$ & 0 & $\mathrm{C}$ & 0 & $b$ \\
\hline & Nov - Jan & 5 & $b$ & 6 & a & 6 & $a$ & 4 & $a$ & 4 & a \\
\hline & Feb - Apr & 3 & $\mathrm{C}$ & 0 & $\mathrm{~b}$ & 1 & $\mathrm{~b}$ & 0 & $\mathrm{~b}$ & 1 & $\mathrm{~b}$ \\
\hline & May - Jul & 6 & $b$ & 0 & $b$ & 0 & $d$ & 0 & $C$ & 0 & C \\
\hline \multirow{4}{*}{ ICS-95 } & Jul - Oct & 38 & $a$ & 9 & $\mathrm{a}$ & 2 & $\mathrm{C}$ & 0 & $\mathrm{C}$ & 0 & C \\
\hline & Nov - Jan & 21 & $b$ & 11 & a & 9 & $a$ & 7 & a & 7 & a \\
\hline & Feb - Apr & 12 & $c$ & 2 & $b$ & 5 & $\mathrm{~b}$ & 1 & $\mathrm{~b}$ & 4 & $\mathrm{~b}$ \\
\hline & May - Jul & 21 & $b$ & 0 & C & 0 & $d$ & 0 & $d$ & 0 & C \\
\hline \multirow{4}{*}{ LK-40 } & Jul - Oct & 4 & $b$ & 4 & $\mathrm{a}$ & 4 & $\mathrm{a}$ & 2 & $a$ & 3 & a \\
\hline & Nov - Jan & 2 & $C$ & 4 & $a b$ & 2 & $b$ & 3 & $a$ & 2 & a \\
\hline & Feb - Apr & 5 & $b$ & 1 & C & 1 & $C$ & 0 & $b$ & 1 & $b$ \\
\hline & may - jul & 14 & $\mathrm{a}$ & 3 & $\mathrm{~b}$ & 0 & $d$ & 0 & $\mathrm{~b}$ & 0 & $\mathrm{~b}$ \\
\hline
\end{tabular}

${ }_{1}^{1}$ Different letters in the column indicate significant differences between the evaluation periods per clone, through tests for multiple comparisons by Conover method ( $95 \%$ confidence interval), after the Kruskal Wallis test. 
Borchert et al. (2005) and Borchert (2015) proposed a photoperiodic timing mechanism for the tropics based on the change in day length that is only large enough around the equinoxes (5 to 7 minutes in 20 days) to affect plant development. Floral induction could occur around the March equinox (for the study area), so that, to induce flowering cocoa, changes in day length could be an additional factor in the transition from dry to wet seasons.

Adjaloo et al. (2012) found that, flowering of the cocoa trees are affected by high precipitation values, light intensity and temperature; however, rainfall had the greatest influence on the phenological cycle of the cocoa plant in the studied bh-T.

The number of fruits from 0 to 2 months had a significant correlation $(p<0.001)$ with precipitation and water balance of 0.36 and 0.35 , respectively. On the other hand, the number of fruits correlated significantly with PAR radiation $(p<0.001)$ and ETo $(p<0.001)$, reaching values of 0.28 and 0.29 . The number of immature leaves showed a significant inverse correlation with precipitation ( $P$ value 0.018 ), water balance $(p=0.029)$ and PAR hours between 750 and $2200 \mu \mathrm{mol} \mathrm{m} \mathrm{m}^{-2} \mathrm{~s}^{-1}(\mathrm{p}=0.018)$ with values of $-0.10,-0.09$ and -0.10 . This means that, there is a higher number of immature leaves when there is low rainfall, as occurred in January and March (Table 3, Figure 3). In this sense, Moser et al. (2010) demonstrated that, soil moisture contents near of the theoretical permanent wilting point did not affect the production of leaves, branches, stems and roots in cocoa trees.

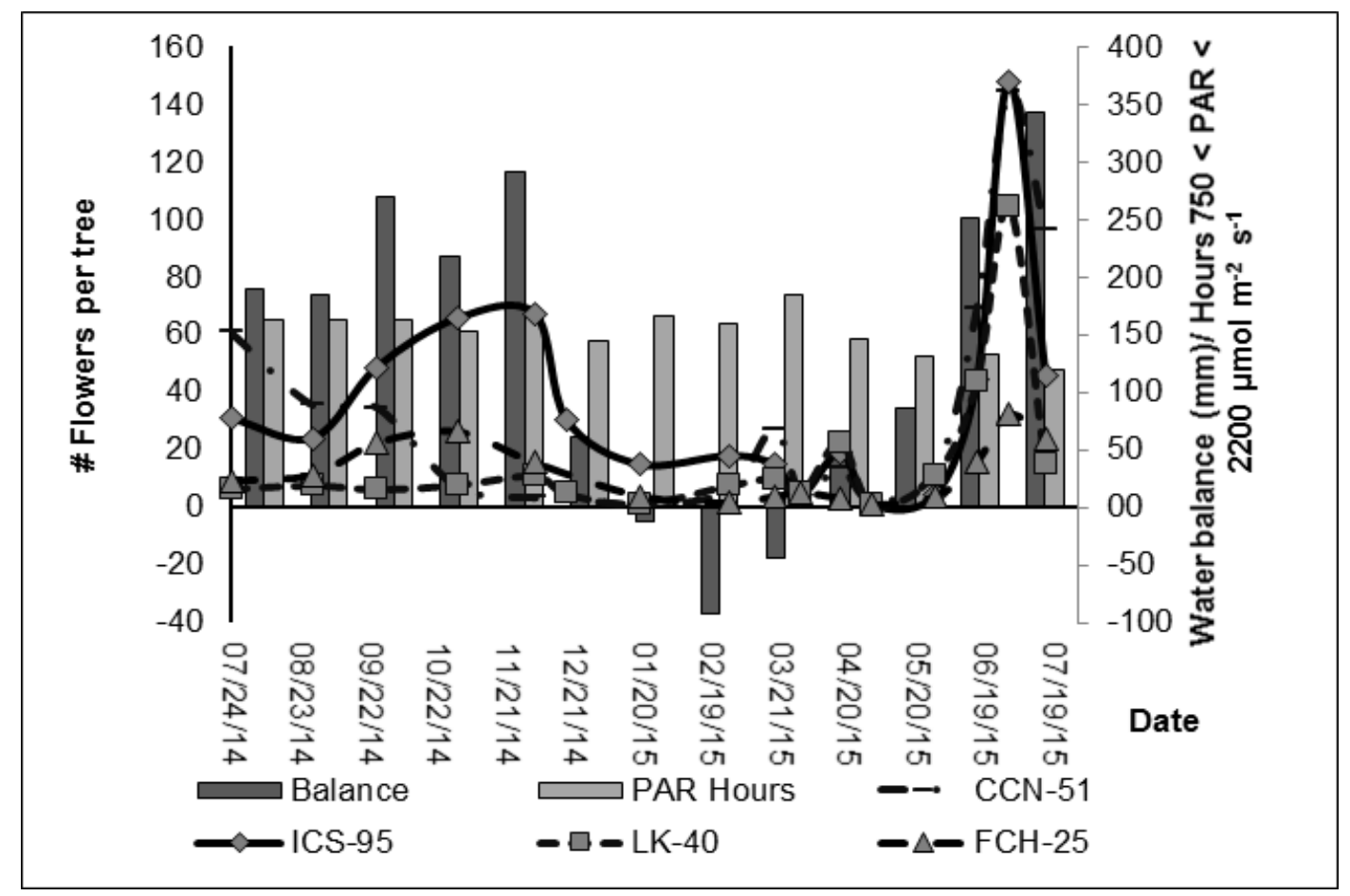

Figure 3 - Distribution of number of flowers per tree in cocoa clones CCN-51, ICS-95, LK-40 and FCH-25; water balance and number of hours with photosynthetically active radiation (PAR) between 750 and $2200 \mu \mathrm{mol} \mathrm{m}^{-2} \mathrm{~s}^{-1}$. July 2014 to July 2015.

The four clones studied showed the highest proportion of apical buds in the F1 and F2 stages (in growth and leaf development) (Table 4) and the highest growth of branches and number of immature leaves between January and March 2015, before the equinox (Tables 3 and 4 ), this coincides with the concepts of Borchert (2015) who mentions that the vegetative development and the phenomenon of bud dormancy break in tropical trees is related to the increase in insolation which occurs before the equinoxes, usually in March and sometimes in August.

\section{Characterization of the phenology of regional and universal clones}

The CCN-51, ICS-95, LK-40 and FCH-25 clones achieved maximum flowering at stage $\mathrm{BBCH} 69$
(Niemenak et al., 2010) between June and July 2015 (Figure 4, 5, 6 and 7), when a positive water balance was presented, with an average of 145, 148, 104 and 32 flowers tree ${ }^{-1}$ day $^{-1}$, respectively; however, the $\mathrm{FCH}$ 25 (Figure 5) and ICS-95 (Figure 6) clones presented another lower intensity peak flowering at stage $\mathrm{BBCH}$ 65, from September to October 2014 and December 2014, with 27 and 67 flowers tree ${ }^{-1}$ day $^{-1}$, respectively (Table 2; Figures 3, 4, 5, 6 and 7).

The ICS-95 clone developed the largest number of flowers with a total of 12778 flowers tree ${ }^{-1}$ year ${ }^{-1}$, followed by CCN-51 with 11435 flowers tree ${ }^{-1}$ year $^{-1}$ and the clones LK-40 and FCH-25 with 4982 flowers tree- year $^{-1}$ (Table 5). According to Niemenak et al. (2010) cocoa can produce up to 120000 flowers tree $^{-1}$ year $^{-1}$. Hasenstein \& Zavada (2001) report that 
the TSH-565 clone produces more than 2000 flowers fruit $^{-1}$.

The CCN-51 and LK-40 clones presented an annual flowering pattern between June and July, while ICS-95 and FCH-25 had a sub-annual pattern, with two episodes in the year, one from June to July and the other from September to October. At the maximum flowering point a high synchrony was observed with a duration of 30 days (Figure 3). Newstrom et al. (1994) found that in Costa Rica, $55 \%$ of the trees had subannual and annual 29\% flowering patterns in tropical moist forest conditions. The predominant flowering type was the subannual pattern, as observed in cocoa.

Table 3 - Median (M) of the reproductive variables by periods of evaluation for the clones CCN-51, FCH-25, ICS-95 and LK-40 in bh-T.

\begin{tabular}{|c|c|c|c|c|c|c|c|}
\hline \multirow[t]{2}{*}{ Clone } & \multirow[t]{2}{*}{ Period } & \multicolumn{2}{|c|}{ Number of mature leaves } & \multicolumn{2}{|c|}{ Number of inmature leaves } & \multicolumn{2}{|c|}{$\begin{array}{l}\text { Length of branches } \\
\text { Growth in } \mathrm{cm}^{-1} \mathrm{day}^{-1}\end{array}$} \\
\hline & & \multicolumn{2}{|c|}{$M$} & \multicolumn{2}{|c|}{$\mathrm{M}$} & \multicolumn{2}{|c|}{$M$} \\
\hline \multirow{4}{*}{ CCN-51 } & 1 & 16 & $c^{1}$ & 0 & $a b$ & 0.000 & $a b$ \\
\hline & 2 & 11 & c & 0 & $a b$ & 0.000 & b \\
\hline & 3 & 25 & $b$ & 0 & $\mathrm{a}$ & 0.100 & a \\
\hline & 4 & 39 & a & 0 & $\mathrm{~b}$ & 0.067 & $a b$ \\
\hline \multirow{4}{*}{$\mathrm{FCH}-25$} & 1 & 11 & c & 3 & a & 0.171 & a \\
\hline & 2 & 15 & $b$ & 0 & $a$ & 0.007 & a \\
\hline & 3 & 27 & a & 0 & a & 0.160 & a \\
\hline & 4 & 33 & a & 3 & $\mathrm{a}$ & 0.076 & a \\
\hline \multirow{4}{*}{ ICS-95 } & 1 & 11 & $\mathrm{~b}$ & 0 & $a$ & 0.000 & $\mathrm{bc}$ \\
\hline & 2 & 10 & $b$ & 0 & $a$ & 0.015 & $c$ \\
\hline & 3 & 10 & $b$ & 0 & $a$ & 0.092 & $a$ \\
\hline & 4 & 13 & $a$ & 0 & $a$ & 0.089 & $a b$ \\
\hline \multirow{4}{*}{ LK-40 } & 1 & 12 & $b$ & 0 & $a$ & 0.000 & $b$ \\
\hline & 2 & 8 & $c$ & 0 & $a$ & 0.000 & $b$ \\
\hline & 3 & 13 & $\mathrm{bc}$ & 0 & $a$ & 0.079 & a \\
\hline & 4 & 28 & $a$ & 0 & $a$ & 0.111 & $a$ \\
\hline
\end{tabular}

${ }_{1}^{1}$ Different letters indicate significant differences between the evaluation periods per clone, through tests for multiple comparisons by Conover method ( $95 \%$ confidence interval), after the Kruskal Wallis test.

Table 4 - Proportion of branches in F1, F2, I1, I2, I3 stages (Greathouse et al., 1971), in the cocoa clones CCN-51, ICS-95, LK-40 and FCH-25. August 2014 to July 2015.

\begin{tabular}{lrrrrrrrrrrrrrrrrrrrrr}
\hline \multicolumn{1}{l}{ Date } & \multicolumn{1}{c}{ CCN-51 (\%) } & \multicolumn{1}{c}{ FCH-25 $(\%)$} & \multicolumn{1}{c}{ ICS-95 $(\%)$} & \multicolumn{1}{c}{ LK-40 (\%) } \\
& F1 & F2 & I1 & I2 & I3 & F1 & F2 & I1 & I2 & I3 & F1 & F2 & I1 & I2 & I3 & F1 & F2 & I1 & I2 & I3 \\
\hline $29 / 08 / 2014$ & 10 & 20 & 0 & 70 & 0 & 40 & 30 & 10 & 20 & 0 & 20 & 10 & 10 & 60 & 0 & 30 & 0 & 10 & 50 & 10 \\
$26 / 09 / 2014$ & 20 & 0 & 20 & 10 & 50 & 30 & 20 & 40 & 0 & 10 & 20 & 0 & 10 & 0 & 70 & 30 & 0 & 0 & 0 & 70 \\
$31 / 10 / 2014$ & 10 & 10 & 10 & 20 & 50 & 20 & 20 & 20 & 40 & 0 & 10 & 0 & 0 & 0 & 90 & 50 & 10 & 0 & 10 & 30 \\
$04 / 12 / 2014$ & 0 & 0 & 0 & 20 & 80 & 20 & 20 & 10 & 20 & 30 & 20 & 0 & 0 & 0 & 80 & 40 & 0 & 0 & 20 & 40 \\
$27 / 02 / 2015$ & 10 & 0 & 0 & 50 & 40 & 30 & 30 & 20 & 10 & 10 & 10 & 0 & 10 & 40 & 40 & 30 & 20 & 20 & 20 & 10 \\
$19 / 03 / 2015$ & 10 & 0 & 20 & 40 & 30 & 10 & 20 & 10 & 10 & 50 & 20 & 0 & 20 & 20 & 40 & 30 & 10 & 20 & 20 & 20 \\
$31 / 03 / 2015$ & 10 & 20 & 10 & 20 & 40 & 10 & 10 & 20 & 40 & 20 & 0 & 30 & 50 & 10 & 10 & 20 & 40 & 10 & 20 & 10 \\
$01 / 05 / 2015$ & 0 & 0 & 0 & 90 & 10 & 0 & 10 & 10 & 30 & 50 & 0 & 0 & 0 & 80 & 20 & 30 & 0 & 0 & 70 & 0 \\
$29 / 05 / 2015$ & 0 & 10 & 10 & 50 & 30 & 0 & 0 & 70 & 20 & 10 & 0 & 0 & 40 & 40 & 20 & 0 & 0 & 10 & 80 & 10 \\
$16 / 06 / 2015$ & 10 & 0 & 0 & 10 & 80 & 0 & 20 & 10 & 40 & 30 & 10 & 10 & 0 & 50 & 30 & 0 & 0 & 0 & 30 & 70 \\
$30 / 06 / 2015$ & 0 & 0 & 10 & 10 & 80 & 0 & 0 & 20 & 80 & 0 & 0 & 0 & 20 & 40 & 40 & 0 & 0 & 0 & 40 & 60 \\
$16 / 07 / 2015$ & 0 & 0 & 20 & 40 & 40 & 0 & 0 & 20 & 50 & 30 & 0 & 0 & 0 & 50 & 50 & 0 & 0 & 30 & 0 & 70 \\
\hline
\end{tabular}


The maximum number of fruits less than two months, corresponding from $\mathrm{BBCH} 70$ to $\mathrm{BBCH} 71$ stages (Niemenak et al., 2010) occurred between July and September for CCN-51 and LK-40; between September and October for $\mathrm{FCH}-25$ and between October and December for ICS-95, with a significant correlation $(p<0.001)$ of 0.52 with the number of open flowers. The maximum of fruits quantified was 63,11 , 13 and 28 fruits tree ${ }^{-1}$ sampling $^{-1}$, respectively.

The ICS-95 clone with less than 2 months of development reached the highest amount, followed by CCN-51 and LK-40, with no significant difference between the last two $(p=0.980)$ and $\mathrm{FCH}-25$ had the lowest average (Table 5).

Fruits between two and four months, corresponding to maximum filling period (stages $\mathrm{BBCH} 72$ to $\mathrm{BBCH}$ 79; Niemenak et al., 2010) were presented from August to December in CCN-51, from September to December in LK-40, and in ICS-95 and FCH-25 began in October and ended in December and February respectively (Table 2). The clone ICS-95 reached fruit numbers significantly higher compared with the other clones (Table 5).

The highest fruit numbers in those with more than four months of growth $(\mathrm{BBCH} 80$ to $\mathrm{BBCH} 89$ stages) was presented between October and December for CCN-51, between August and December for LK-40 and in January for ICS-95 and FCH-25, with an annual fructification pattern at all cases (Table 2, Figures 8 to 11). LK-40 and ICS-95 clones produced the highest amount of available fruit, without significant differences between them ( $p=0.627)$, surpassing CCN51 and $\mathrm{FCH}-25$ ( $\mathrm{p}$ value 0.145). LK-40 and ICS-95 could be expected to produce a higher amount of fruit than $\mathrm{CCN}-51$ and $\mathrm{FCH}-25$, in bh-T.

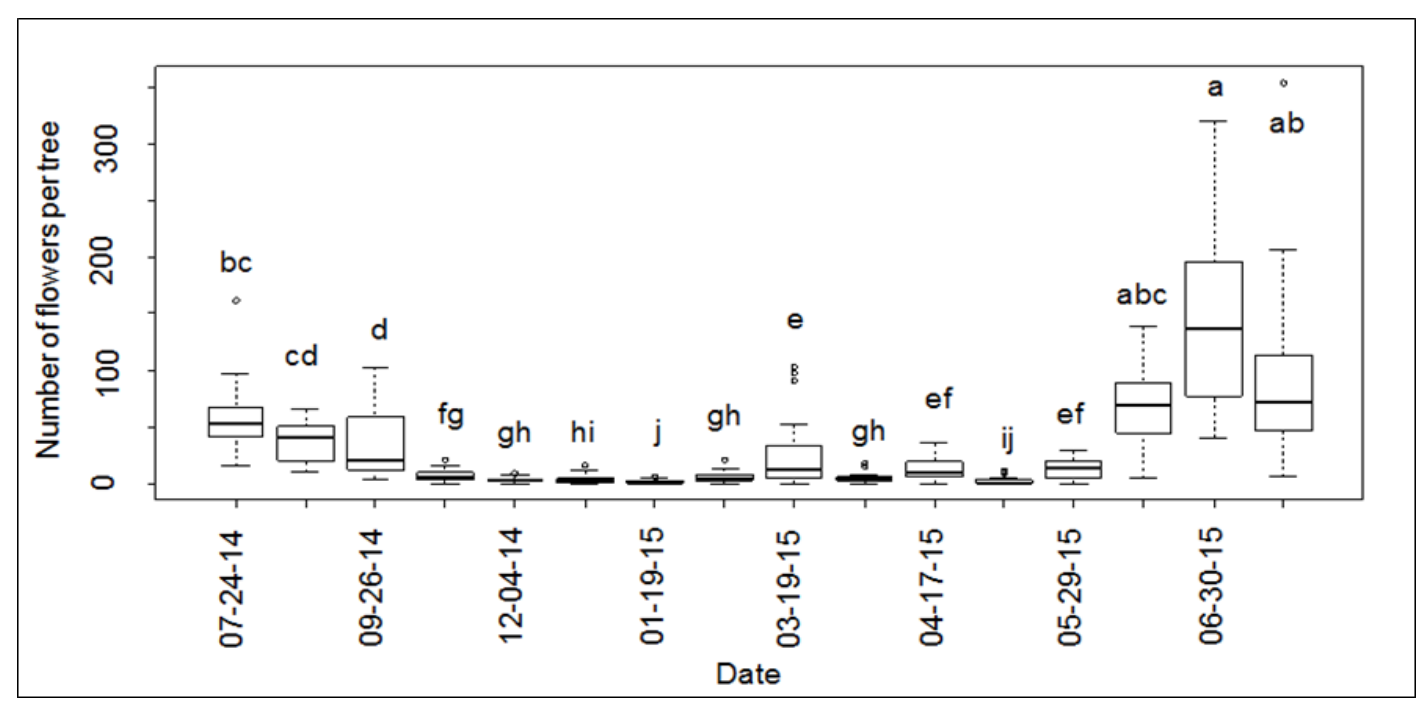

Figure 4 - Distribution of the number of flowers in the clone CCN-51. Different letters indicate significant differences through tests for multiple comparisons by Conover method ( $95 \%$ confidence interval), after the Kruskal Wallis test.

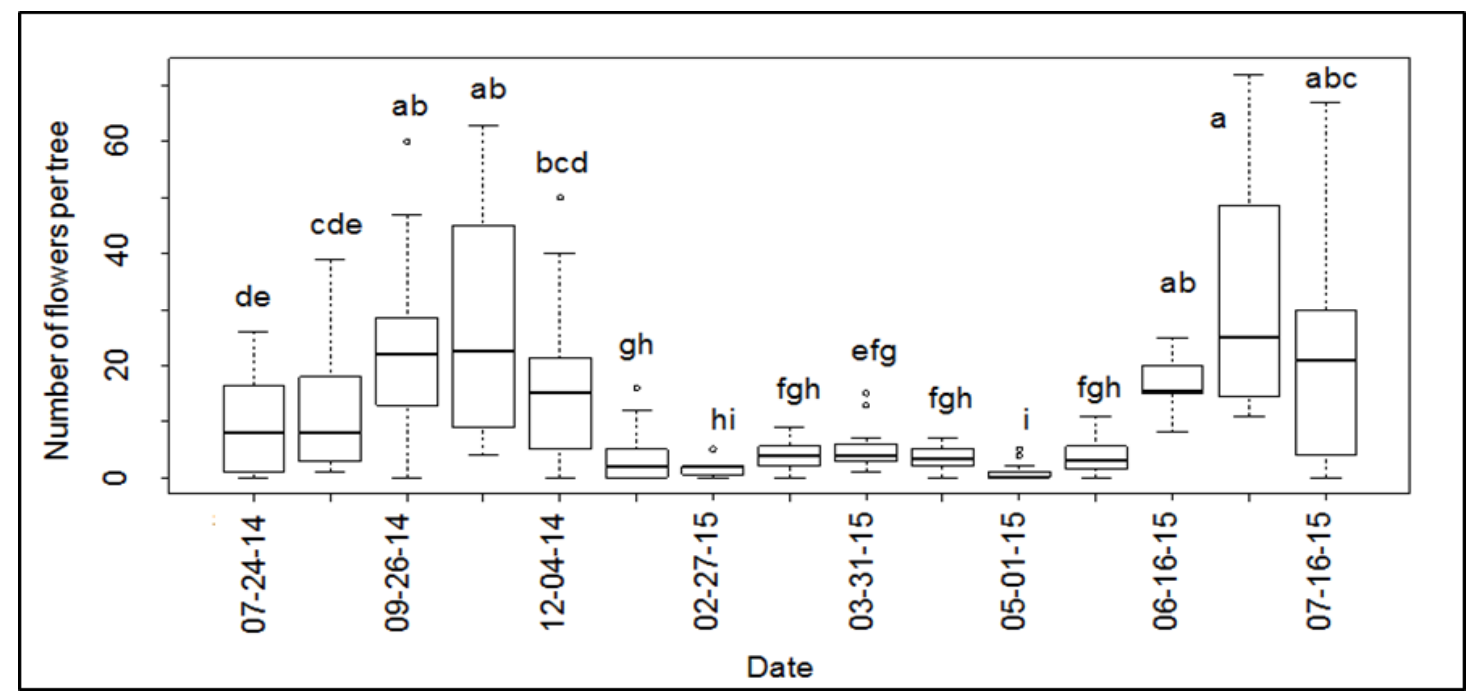

Figure 5 - Distribution of the number of flowers in the clone FCH-25. Different letters indicate significant differences through tests for multiple comparisons by Conover method (95\% confidence interval), after the Kruskal Wallis test. 


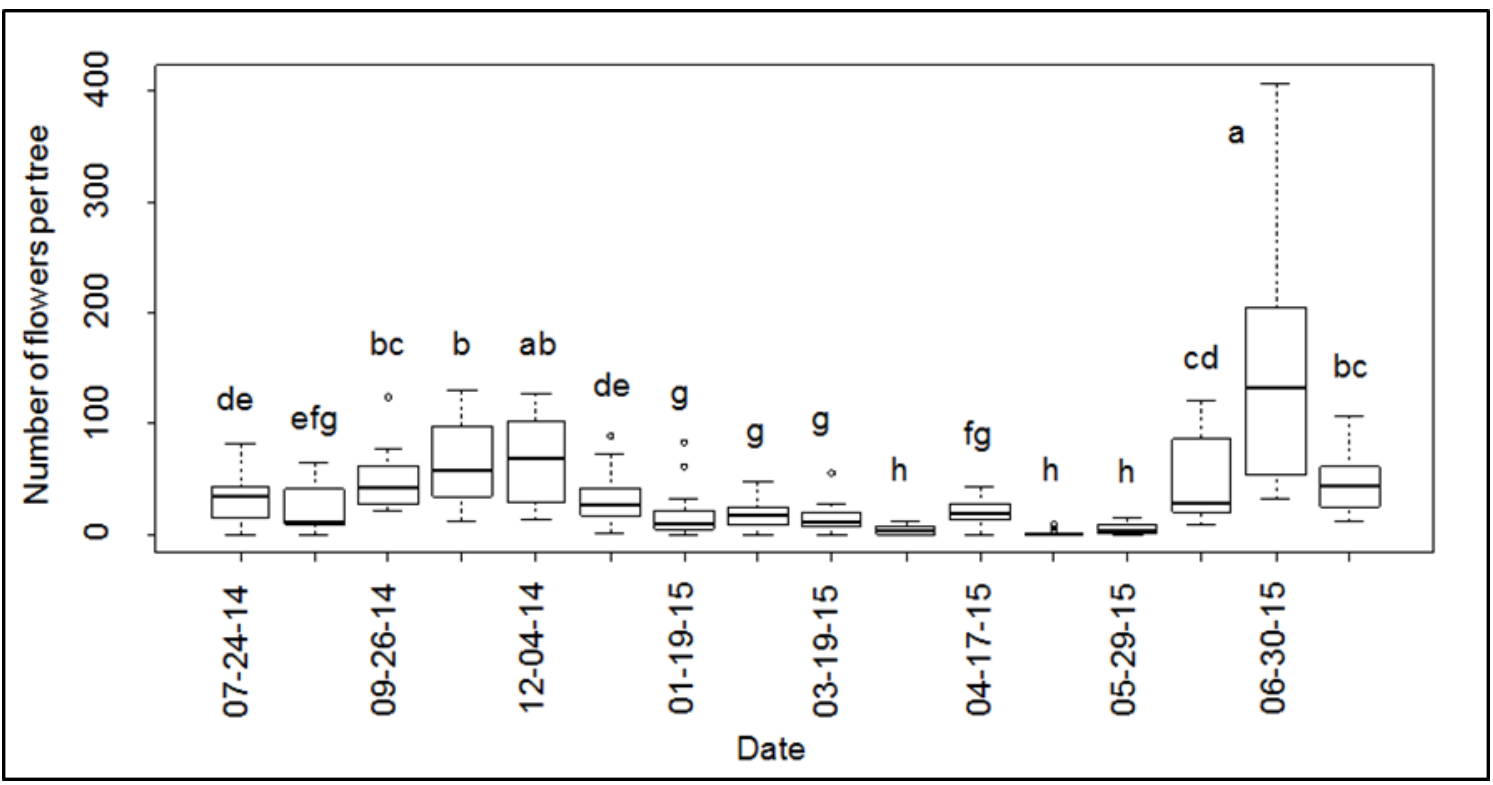

Figure 6 - Distribution of the number of flowers in the clone ICS-95, in bh-T. Different letters indicate significant differences through tests for multiple comparisons by Conover method ( $95 \%$ confidence interval), after the Kruskal Wallis test.

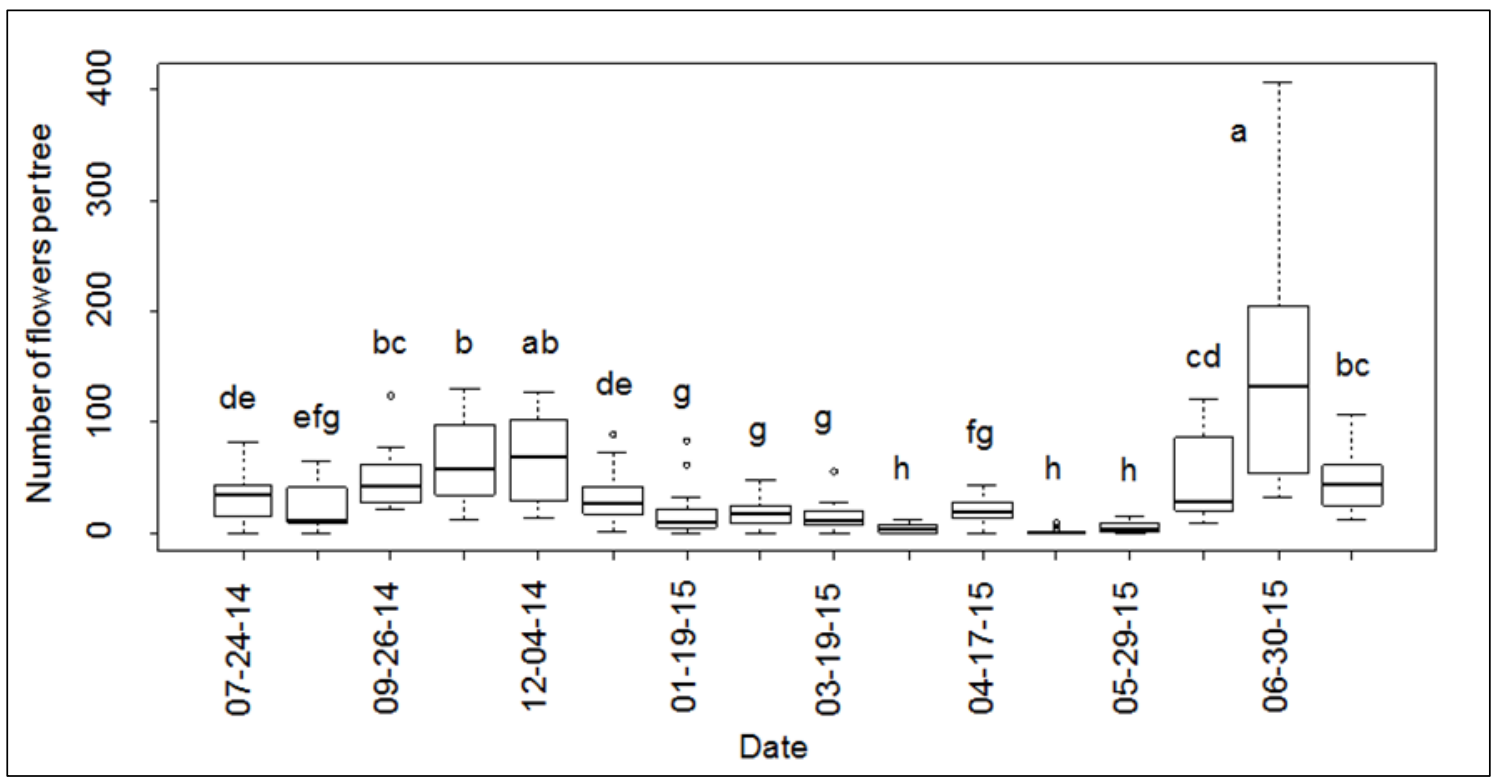

Figure 7 - Distribution of the number of flowers in the clone LK-40, in bh-T. Different letters indicate significant differences through tests for multiple comparisons by Conover method ( $95 \%$ confidence interval), after the Kruskal Wallis test

Table 5 - Median (M) of the reproductive variables number of flowers (flowers tree ${ }^{-1}$ day $^{-1}$ ), fruits less than two months, fruits from two to four months and major than four months; and number of dry fruits (fruits tree ${ }^{-1}$ sampling $^{-1}$ ) for the clones CCN-51, ICS-95, FCH-25, LK-40, in bh-T.

\begin{tabular}{|c|c|c|c|c|c|c|c|c|}
\hline \multirow{2}{*}{$\begin{array}{l}\text { Variable } \\
\text { Flores }\end{array}$} & \multicolumn{2}{|c|}{$\begin{array}{c}\mathrm{CCN}-51 \\
M\end{array}$} & \multicolumn{2}{|c|}{$\begin{array}{c}\mathrm{FCH}-25 \\
\mathrm{M}\end{array}$} & \multicolumn{2}{|c|}{$\begin{array}{c}\text { ICS-95 } \\
M\end{array}$} & \multicolumn{2}{|c|}{$\begin{array}{c}\text { LK-40 } \\
\mathrm{M}\end{array}$} \\
\hline & 8 & $\mathrm{~b}^{1}$ & 5 & C & 20 & $a$ & 5 & C \\
\hline Fruits $<2$ months & 2 & $b$ & 1 & c & 5 & a & 3 & b \\
\hline Fruits $2-4$ months & 0 & $\mathrm{~b}$ & 1 & $b$ & 3 & a & 1 & b \\
\hline Fruits $>4$ months & 0 & $\mathrm{~b}$ & 0 & $\mathrm{~b}$ & 0 & a & 1 & a \\
\hline Dry Fruits & 1 & $\mathrm{a}$ & 0 & $b$ & 2 & a & 1 & b \\
\hline
\end{tabular}

${ }^{1}$ Different letters indicate significant differences among clones, through tests for multiple comparisons by Conover method (95\% confidence interval), after the Kruskal Wallis test. 
ICS-95 and FCH-25 clones retained this amount for only one month, while LK-40 did so for four months and $\mathrm{CCN}-51$ for two months.

In a period of more than four months, with maximum presence of fruits, the average number reached was of 11 fruits tree-1 for $\mathrm{CCN}-51,18$ fruits tree-1 for ICS-95, 7 fruits tree-1 for LK-40 and 6 fruits tree-1 for $\mathrm{FCH}-25$. The clones ICS-95 and $\mathrm{FCH}-25$ retained this amount for only one month, while LK-40 do that for four months and $\mathrm{CCN}-51$ for two months.
The fruit filling until harvest period $(\mathrm{BBCH}$ BBCH 8970 stages) lasted for 210 days (July to February). In March, the lower amount of fruits for all the ages was quantified in the four studied clones, since the main harvest was completed in February.

The highest drying fruits occurred in the CCN-51 and ICS-95 clones, with no significant differences between them ( $P$ value 0.766$)$, followed by LK-40 and FCH-25 (Table 5).

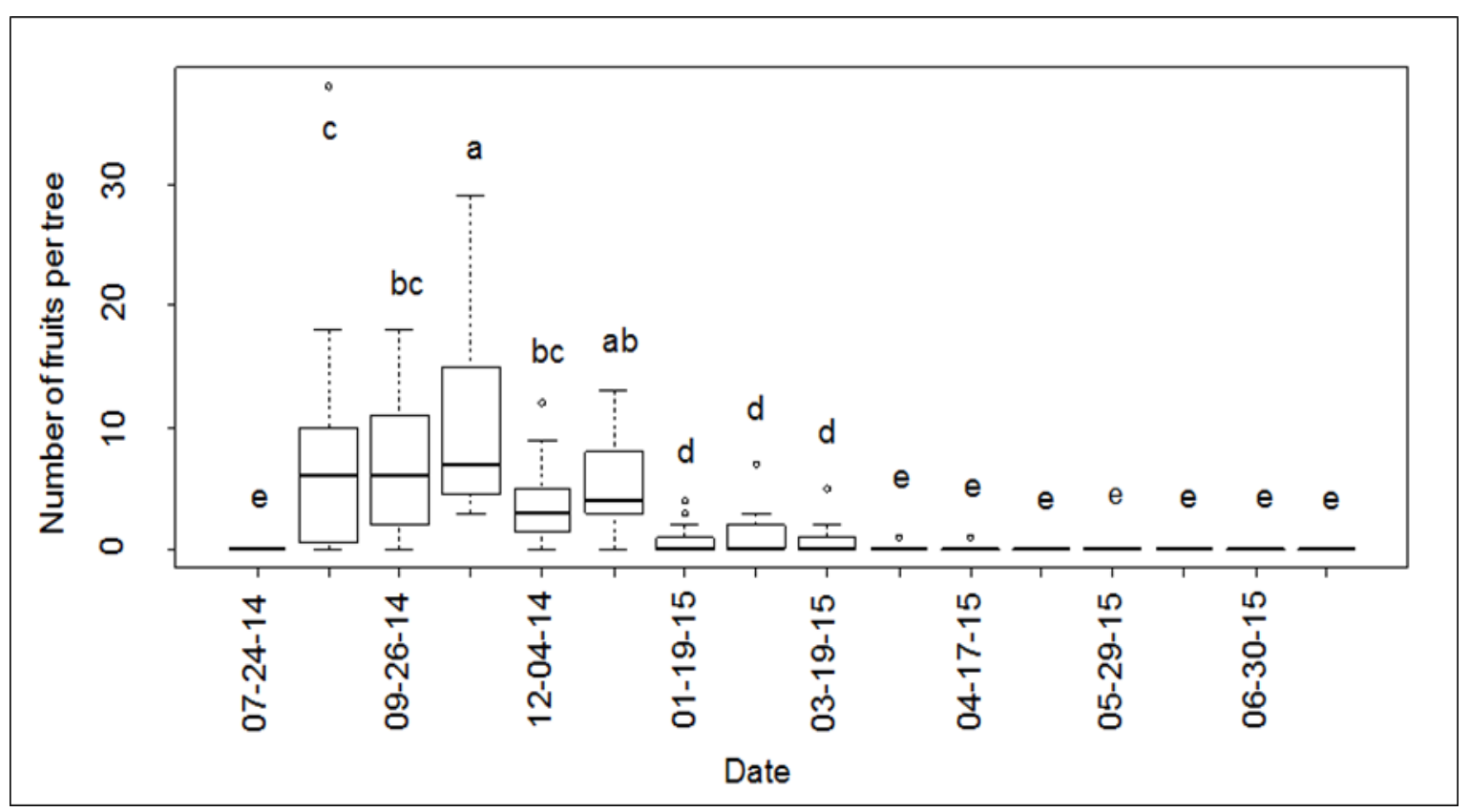

Figure 8 - Number of fruits older than four months of CCN-51 clone (different letters indicate significant differences with Conover's test, significance level of 95\%).

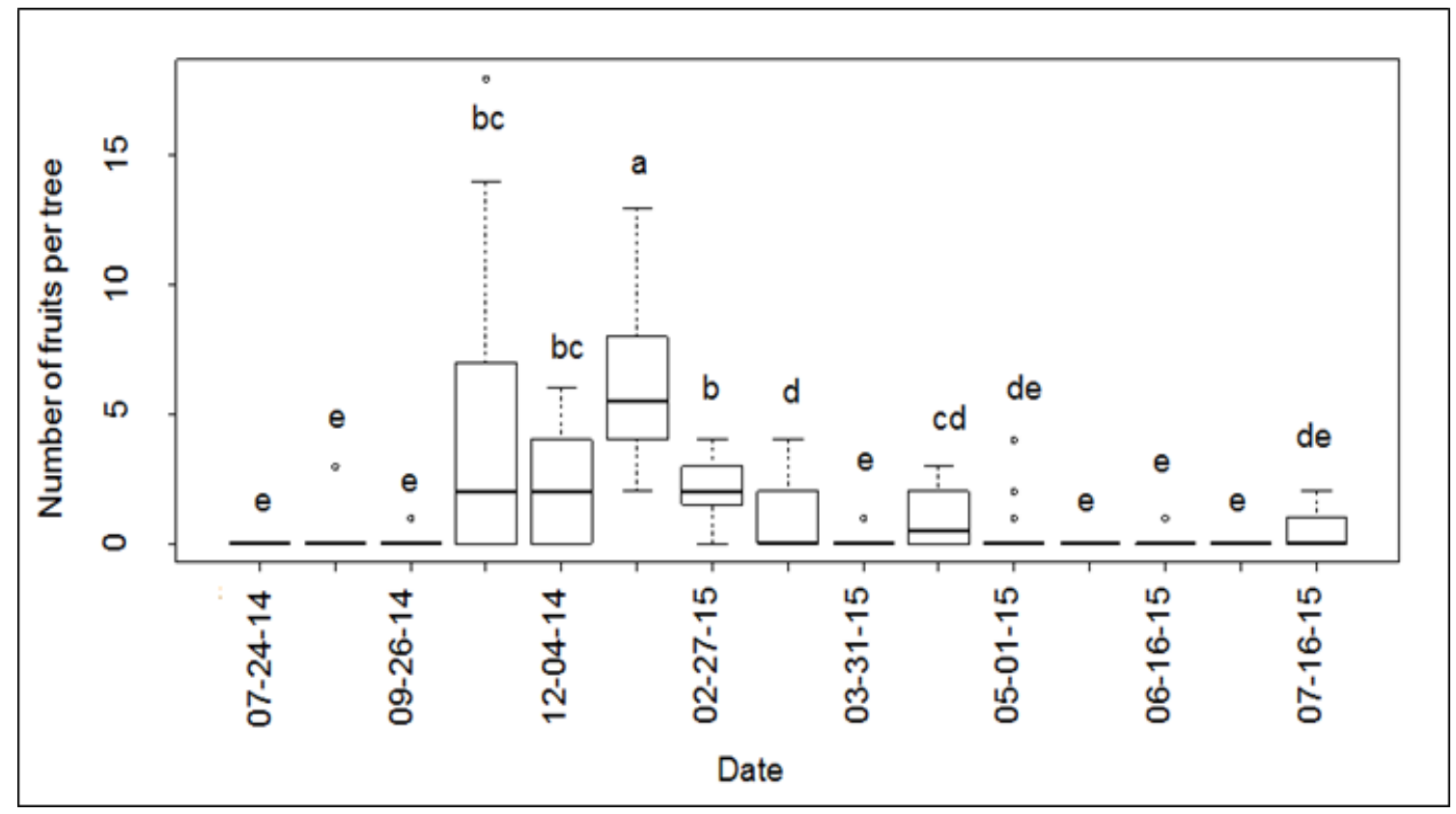

Figure 9 - Number of fruits older than four months of $\mathrm{FCH}-25$ clone (different letters indicate significant differences with Conover's test, significance level of $95 \%$ ). 


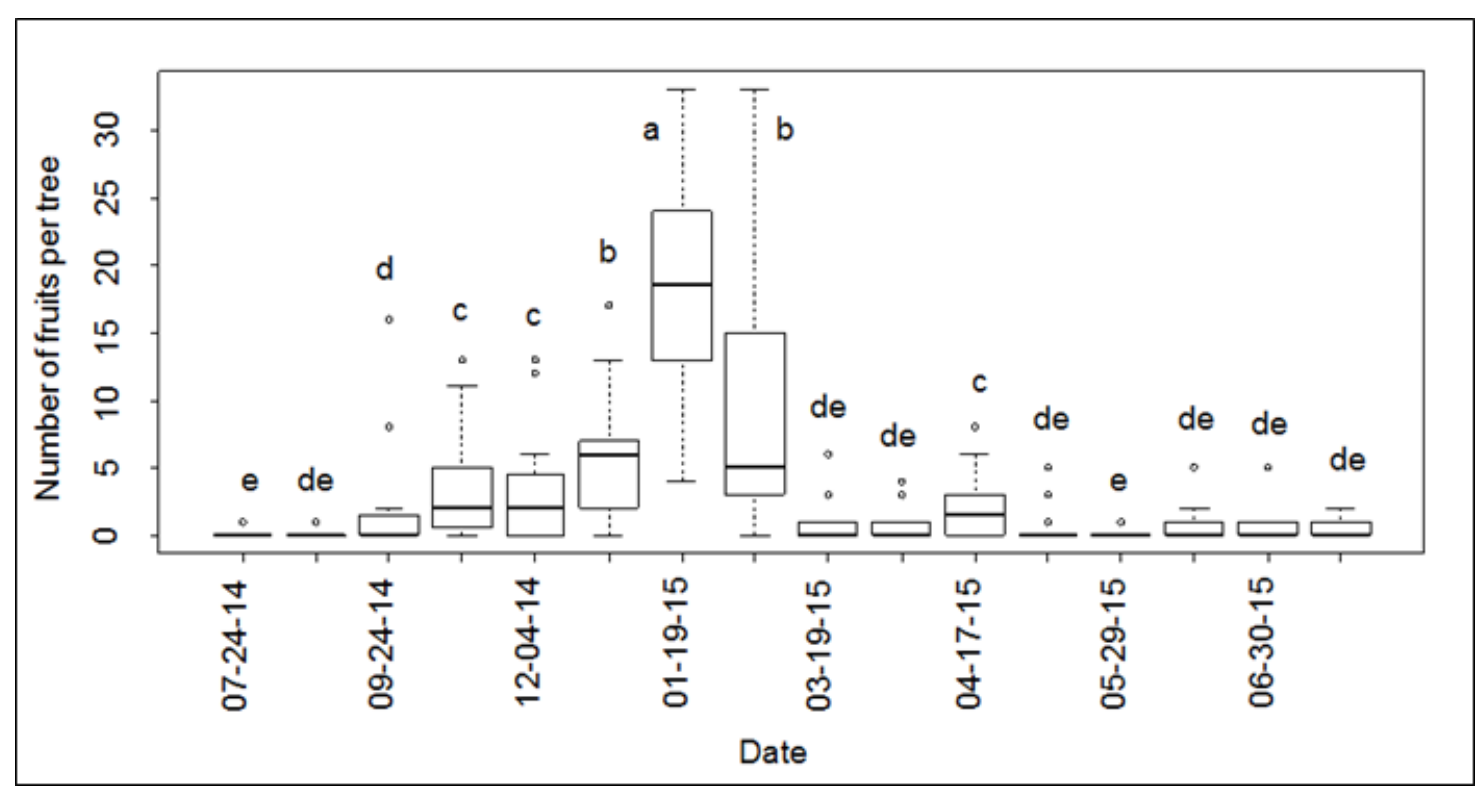

Figure 10 - Number of fruits older than four months of ICS-95 clone (different letters indicate significant differences with Conover's test, significance level of 95\%).

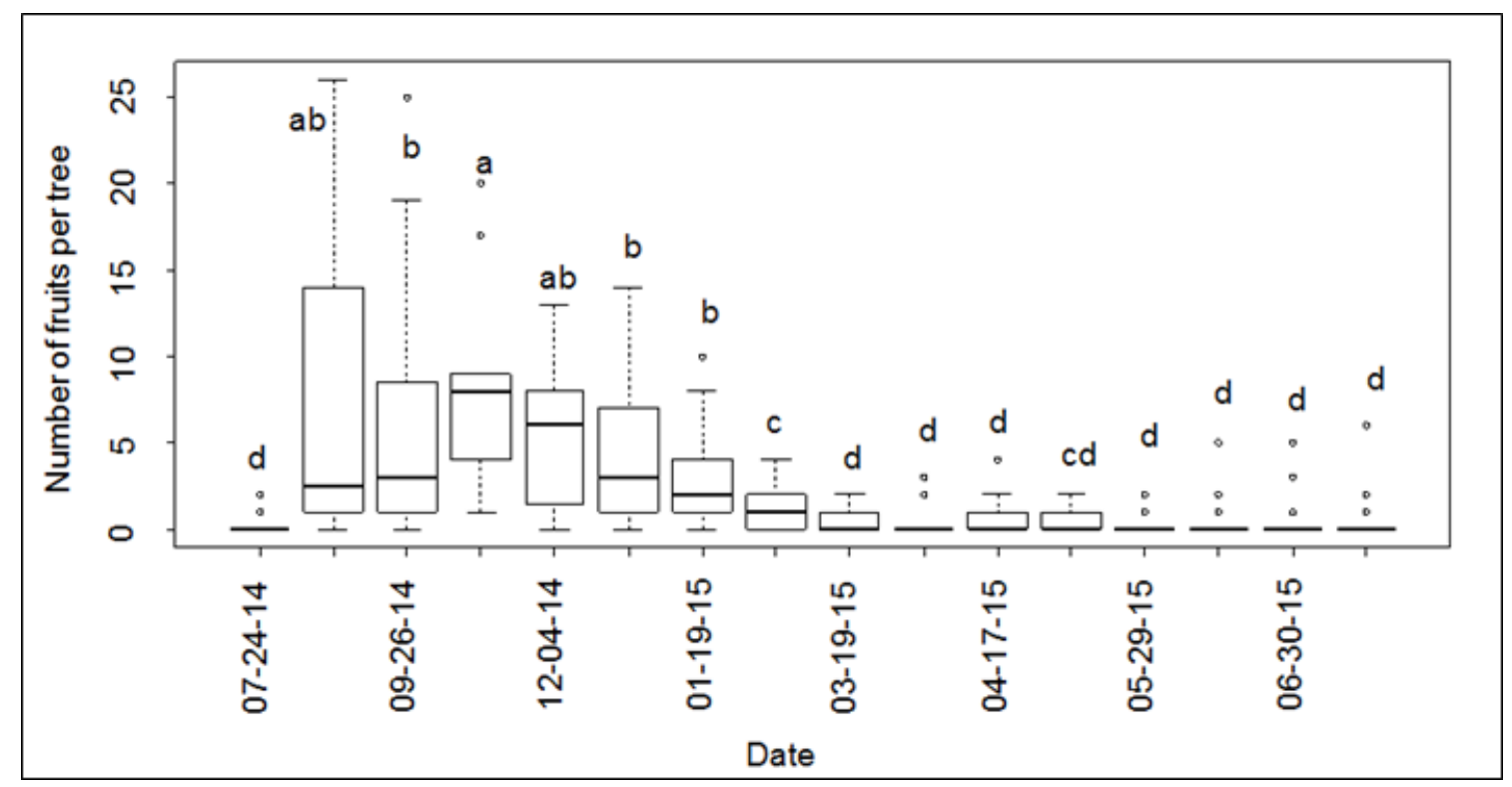

Figure 11 - Number of fruits older than four months of LK-40 clone (different letters indicate significant differences with Conover's test, significance level of 95\%).

A total of $166,59,44$ and 40 fruits tree ${ }^{-1}$ were dried during the study period corresponding to 10.6 , 2.8, 2.8 and $2.6 \mathrm{~kg}$ of dry cocoa tree-1, considering the ear index of the clones CCN-51, ICS-95, LK-40 and $\mathrm{FCH}-25$, respectively.

There was a positive correlation between the number of dry fruits and fruits less than two months, and also from two to four months and greater than four months $(p<0.001)$ of $0.28,0.51$ and 0.46 , respectively. In other words, the drying fruit is related to the high quantity of fruit in filling, especially if more than two months have passed. In this sense, Alvim (1977) mentions that the fruits greater than 80 days are a much stronger sink than the small fruits, in relation with dry matter demand and increase, that reaches a maximum of $2 \mathrm{~g} \mathrm{day}^{-1}$ between 98 and 112 days.

Valle et al. (1990) confirm that fruits during the linear stage of growth (aged more than two months) are a sink capable of causing drying to those that are in the exponential stage of growth (less than two months), stating that the drying fruits is a mechanism used by trees to sustain their production, process that agrees with findings of this study. Groeneveld et al. (2010) found that an increase in yield of $350 \mathrm{~g} \mathrm{tree}^{-1}$ were reached by increasing pollination from $10 \%$ to $40 \%$; however, when pollinating $70 \%$ and $100 \%$ of the flowers, an increase occurred in the percentage of dry fruits or "cherelle wilt". 
The phase of maximum fruit filling greater than two months (Table 2) showed the lowest number of flowers. In this respect Alvim (1977) mentions that the maximum period of fruit filling, expressed as the highest amount of dry matter of fruits in filling corresponds to the period of lowest flowering. Valle et al. (1990) found that by continuously removing all fruits in cocoa trees flowering increased, as there is a balanced of photoassimilate distributions between flowers and fruits. The assertions by Alvim (1977) and Valle et al. (1990) suggesting that fruit filling affects flowering, are consistent with the observations of the present study.

A significant inverse correlation was found between number of mature leaves and fruit numbers in the different growth stages $(P<0.001)$, indicating that as the leaves become mature they contribute to the filling of the fruit and they fall, given their photoassimilates mobilization from source (leaves) to sink (fruits). Similarly, the number of immature leaves had a significant inverse correlation $(P<0.001)$ with the number of fruits, showing that the fruits compete with leaf formation, which is the new sink. In the periods of higher fruit filling, the lowest growth rate of the branches (length-1) and the lowest number of mature leaves were observed in all clones studied (Tables 2 and 3, Figure 12). Thus, during the periods of growth and filling of the fruits, vegetative growth was reduced.

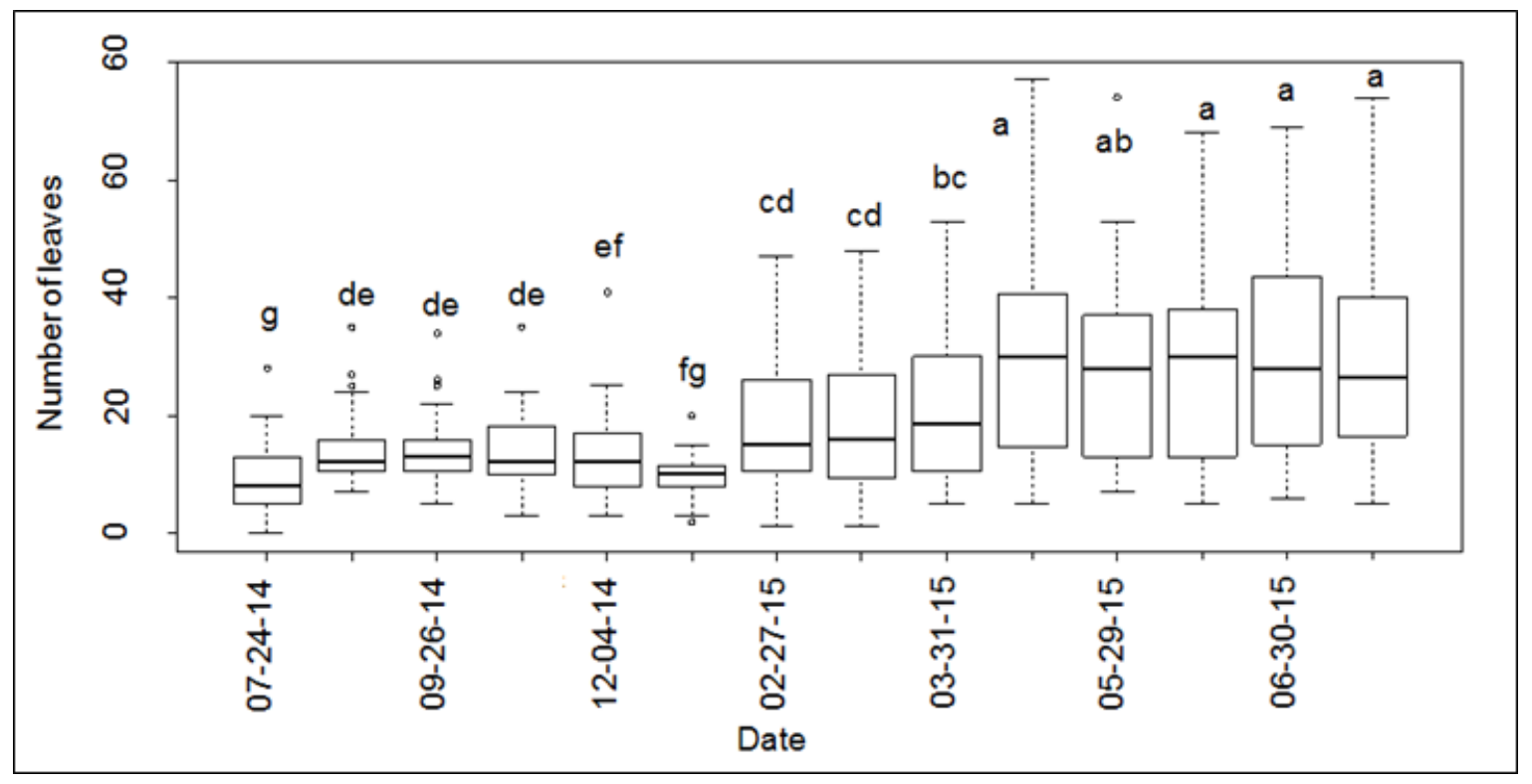

Figure 12 - Number of mature leaves in CCN-51, FCH-25, ICS-95 and LK-40 clones (different letters indicate significant differences between evaluation dates with Conover's test, significance level of 95\%).

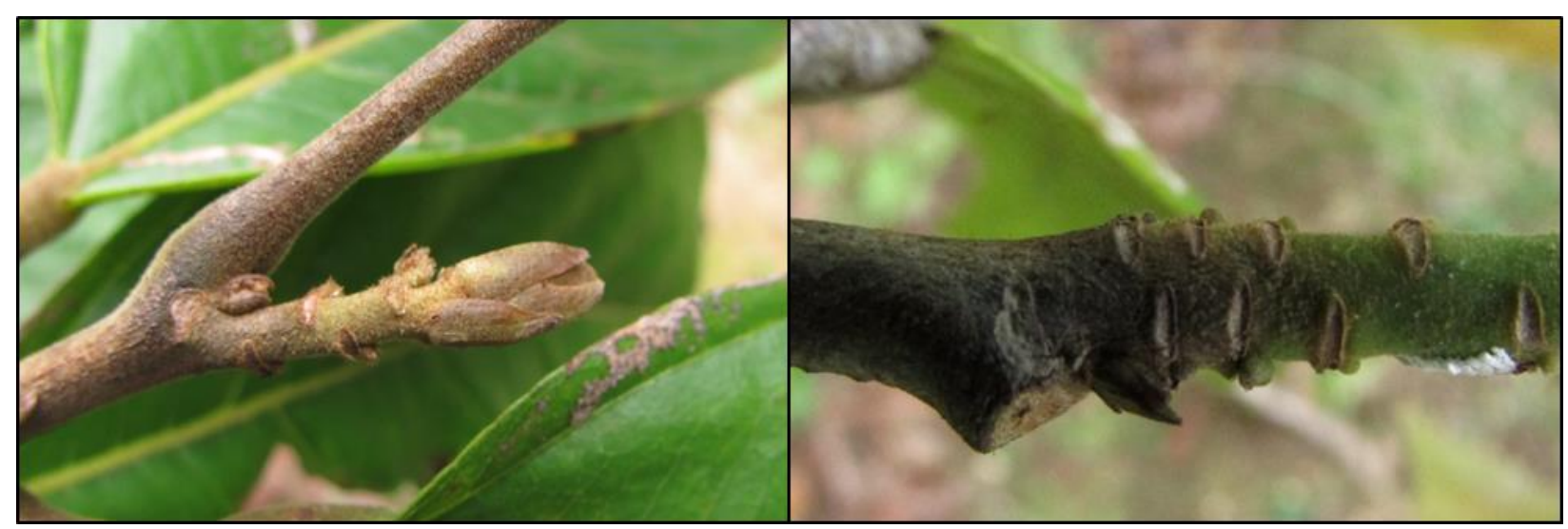

Figure 13 - Left: Branch with failed flushing during cocoa fruit filling. Note the formation of new lateral buds, incipient elongation and absence of leaves. Right: Branch elongation after a failed flushing.

Buds were found during most of the year in $\mathrm{F} 1$ and F2 stages (growth and leaf development). Branch growth and new leaf development were reported from January and February, when most of the fruits were more than four months and the main harvest was being completed (Table 4). The high apical bud activity in August did not produce significant increases in the length of branches nor in the development of leaves (Tables 2, 3 and 4), for the occurrence of this phenomenon in cocoa crops, the name of "failed flushing " is 
proposed (Figure 13). The proportion of buds in dormancy (states I1, I2 and I3) reached 60\% to 75\% from August to March, then increased to $100 \%$ between June and July, coinciding with the period, flowering and fruit filling, in the smaller than two months phase. Reproductive growth predominates during this period.

Vegetative growth in the CCN-51, ICS-95, $\mathrm{FCH}-25$ and LK-40 clones occurred when the fruits surpassed four months, between January and May (Tables 2 and 3) corresponding to the period of photoassimilate demand in these organs because they reach their maturation stage. Almeida \& Valle (1995) mention that fruit growth rates decrease after 106 days of pollination and Hoopen et al. (2012) report that after reaching the maximum diameter, 87 days, fruit growth decreased, giving opportunity to vegetative growth, as observed in the clones studied.

The FCH-25, followed by CCN-51 and LK-40 and ICS-95 clones presented the highest elongation of branches (Table 6), with annual average growth of 54, 37,31 and $33 \mathrm{~cm}^{\text {branch }}{ }^{-1}$, respectively.

Table 6 - Median (M) of vegetative variables evaluated in the CCN-51, ICS-95, FCH-25, LK-40 clones. bh-T.

\begin{tabular}{|c|c|c|c|c|c|c|c|c|}
\hline \multirow{2}{*}{$\frac{\text { Variable }}{\text { Branch lenght (cm) }}$} & \multicolumn{2}{|c|}{$\begin{array}{c}\text { CCN-51 } \\
M\end{array}$} & \multicolumn{2}{|c|}{$\begin{array}{c}\mathrm{FCH}-25 \\
\mathrm{M}\end{array}$} & \multicolumn{2}{|c|}{$\begin{array}{c}\text { ICS-95 } \\
M\end{array}$} & \multicolumn{2}{|c|}{$\begin{array}{c}\text { LK-40 } \\
\mathrm{M}\end{array}$} \\
\hline & 48.5 & $b^{1}$ & 63.0 & $\mathrm{a}$ & 39.3 & $\mathrm{C}$ & 39.0 & $\mathrm{C}$ \\
\hline Number of buds & 33 & $\mathrm{a}$ & 35 & $\mathrm{a}$ & 25 & $\mathrm{C}$ & 29 & $\mathrm{~b}$ \\
\hline Number of branches & 4 & $\mathrm{a}$ & 4 & $\mathrm{a}$ & 0 & $\mathrm{C}$ & 1 & $\mathrm{~b}$ \\
\hline Number of mature leaves & 22 & $\mathrm{a}$ & 21 & a & 11 & $\mathrm{C}$ & 15 & $\mathrm{~b}$ \\
\hline Numberof inmature leaves & 0 & $\mathrm{~b}$ & 2 & $\mathrm{a}$ & 0 & $\mathrm{~b}$ & 0 & $\mathrm{~b}$ \\
\hline
\end{tabular}

${ }_{1}$ Different letters indicate significant differences among clones, through tests for multiple comparisons by Conover method (95\% confidence interval), after the Kruskal Wallis test.

\section{Conclusions}

Both high solar radiation and high rainfall are the triggers of floral induction and the subsequent filling of the cocoa fruits, in bh-T. The vegetative growth rhythm is conditioned by the period of maximum fruit filling and harvest (source: sink ratio).

The LK-40 clone had a similar reproductive growth to that of ICS-95 and significantly higher than that of CCN-51, this suggests a great potential for its commercial implementation in tropical moist forest condition.

The FCH-25 and CCN-51 clones exhibited the highest vegetative growth, but their reproductive performance was significantly lower than that achieved by ICS-95 and LK-40.

The CCN-51, ICS-95, LK-40 and FCH-25 clones cross synchronously through the succession stages: flowering (30 days), fruit filling (210 days) and branch growth (120 days), with an annual periodicity, which correlates with the unimodal rainfall regime.

\section{Acknowledgements}

This research was co-financed by the General System of Royalties SGR in special agreement of cooperation No. 4600000987 between the Government of Antioquia-Secretariat of Agriculture and Rural Development and Universidad Nacional de Colombia, Sede Medellín. We express special thanks to Mr. Nazario Díaz (producer and owner of the Mi Fortuna Farm), to AgroXue Research Group and to the agricultural engineering students of the Universidad de Antioquia - Sede Urabá for their logistical support.

\section{References}

Adjaloo MK, Oduro W, Banful BK (2012) Floral phenology of upper amazon cocoa trees: implications for reproduction and productivity of cocoa. International Scholarly Research Network. Volume 2012, Article ID 461674, 8p.

Allen RG, Pereira LS, Raes D and Smith M (1998) Crop evapotranspiration: Guidelines for computing crop water requirements. United Nations Food and Agriculture Organization, Irrigation and Drainage Paper 56, Rome, Italy, 300p.

Almeida AF, Valle RR (1995) Análise de crescimento do fruto e das sementes de sete genotipos de Theobroma cacao L. Pesquisa Agropecuária Brasileira 30(7): 909-916.

Alvim P de T (1977) Cacao. In: Ecophysiology of Tropical Crops. Eds. P. de T. Alvim and T. T. Kozlowski. Academic Press, New York, p 279-313.

Borchert R (1983) Phenology and Control of Flowering in Tropical Trees. Biotropica 15(2): 81-89.

Borchert R, Renner SS, Calle Z, Navarete D, Tye A, Gautier L, Spichiger R, von Hildebrand P (2005) Photoperiodic induction of synchronous flowering near the equator. Nature 433: 627-629.

Borchert R, Calle Z, Strahler AH. Baertschi A, Magill RE., Broadhead JS, Kamau J, Njoroge J, Muthuri C (2015) Insolation and photoperiodic control of tree development near the equator. New Phytologist 205: 7-13. 
Boyle WA, Bronstein JL (2012) Phenology of tropical understory trees: patterns and correlates. International Journal of Tropical Biology and Conservation 60(4):1415-1430.

Castellanos OF, Torres LM, Fonseca SL, Montañez VM, Sánchez A (2007) Agenda prospectiva de investigación y desarrollo tecnológico para la cadena productiva de cacao-chocolate en Colombia. Universidad Nacional de Colombia. Bogotá D. C. 174p.

Conover WJ (1999) Practical Nonparametric Statistics. $3^{\text {rd }}$ edition. Wiley. 592p.

Decagon Devices, Inc (2015) DataTrac 3. User's manual. Version: February 5, 2015-12:00:22. 75p.

Espinal LS (1977) Zonas de vida o formaciones vegetales de Colombia. Memoria explicativa sobre el mapa ecológico. IGAC. Bogotá. 238p.

Espinal CF; Martínez HJ; Ortiz L (2005) "La cadena del cacao en Colombia: Una mirada global de su estructura y dinámica 1991-2005". Documento de trabajo No. 92. MADR. Observatorio de Agrocadenas Colombia. 51p.

Fedecacao - Federación Nacional de Cacaoteros de Colombia (2015) Guía técnica para el cultivo del cacao. 6ta edición. Bogotá, Colombia. 180p.

Greathouse DC, Laetsch WM, Phinney B0 (1971) The shoot-growth rhythm of a tropical tree, Theobroma cacao. Amer. J. Bot. 58(4): 281-286.

Groeneveld JH, Tscharntke T, Moser G, Clough Y (2010) Experimental evidence for stronger cacao yield limitation by pollination than by plant resources. Perspectives in Plant Ecology, Evolution and Systematics 12: 183-191.

Hasenstein, K. H., Zavada, M. S. 2001. Auxin modification of the incompatibility response in Theobroma cacao. Physiologia Plantarum 112: 113 118.

Hoopen GM, Deberdt P, Mbenoun M and Colas C (2012) Modelling cacao pod growth: implications for disease control. Annals of Applied Biology 160. 260-272.

Moser G, Leuschner C, Hertel D, Hölscher D, Köhler M, Leitner D, Michalzik B, Prihastanti E, Tjitrosemito S, Schwendenmann L (2010) Response of cocoa trees (Theobroma cacao) to a 13-month desiccation period in Sulawesi, Indonesia. Agroforestry Systems 79: 171-187. Springer.

Motamayor, J. C., Risterucci, A. m., Lopez, P. A., Ortiz, C. F., Moreno, A., Lanaud, C. 2002. Cacao domestication 1: the origin of the cacao cultivated by the Mayas. Nature Publishing Group. Heredity 89, 380 - 386.

Müller MW, de Lima AA, Alvim P (2004) Influência do paclobutrazol e do anelamento aplicados em diferentes estádios fenológicos do cacaueiro no controle da floração. Agrotrópica 16(3): 105-110. Centro de Pesquisas do Cacau, llhéus, Bahia, Brasil.
Newstrom LE, Frankie GW, Baker HG (1994) A New Classification for Plant Phenology Based on Flowering Patterns in Lowland Tropical Rain Forest Trees at La Selva, Costa Rica. Biotropica 26(2): 141-159.

Niemenak N, Cilas C, Rohsius C, Bleiholder H, Meier U, Lieberei R (2010) Phenological growth stages of cacao plants (Theobroma sp.): codification and description according to the BBCH scale. Annals of Applied Biology 156 13-24.

Omolaja SS, Aikpokpodion P, Adedeji S, Vwioko DE (2009) Rainfall and temperature effects on flowering and pollen productions in cocoa. African Crop Science Journal 17(1): 41-48.

Pohlert, T. 2014. The Pairwise Multiple Comparison of Mean Rank Package (PMCMR). $R$ package. http://CRAN.R-project.org/package=PMCMR.

R Core Team (2015) R: A language and environment for statistical computing. R Foundation for Statistical Computing, Vienna, Austria. URL https://www.Rproject.org/.

Righi, C. A., Silveira, M., Castro, D. S., Abbud, D. M. 2001. Fenologia e variação temporal do índice de área foliar de três cultivares de seringueira (Hevea spp.).

Agrotrópica 13 (3): 125 - 132. Centro de Pesquisas do Cacau, llhéus, Bahía, Brasil.

Sakai S (2001) Phenological diversity in tropical forests. Population Ecology 43: 77-86.

Swanson JD, Carlson JE, Guiltinan MJ (2008) Comparative flower development in Theobroma cacao based on temporal morphological indicators. Int. J. Plant Sci. 169 (9): 1187-1199.

Thomas, E., van Zonneveld, M., Loo, J., Hodgkin, T., Galluzzi, G., van Etten, J. 2012. Present spatial diversity patterns of Theobroma cacao $L$. in the neotropics reflect genetic differentiation in Pleistocene refugia followed by human-influenced dispersal. PLoS $\begin{array}{llll}\text { ONE } & 7 & (10): & \text { e47676. }\end{array}$ 10.1371/journal.pone.0047676.

Valle RR, Almeida AAF and Leite RM (1990) Energy cost of flowering, fruiting, and cherelle wilt in cacao. Tree Physiology 6, 329- 336. Heron Publishing - Victoria, Canada.

Zuidema PA, Leffelaar PA, Gerritsma W, Mommer L, Anten NPR (2005) A physiological production model for cocoa (Theobroma cacao): model presentation, validation and application. Agricultural Systems 84: 195-225. 